\title{
Powieść szachowa \\ jako powieść historyczna. Nieco przewrotna alternatywa gatunkowa
}

Postępuję z Historią niczym scenograf, który przygotowuje abstrakcyjną dekorację przy użyciu kilku jedynie przedmiotów niezbędnych do akcji. [...] Dla historyka [...] epizod [...] [jest] bez znaczenia, lecz ileż w nim najwyższej antropologicznej treści! [...] chodzi o to [...], by Historia sama $w$ sobie została zrozumiana i przemyślana jako sytuacja egzystencjalna.

Milan Kundera, Sztuka powieści $i^{1}$

Inną techniką (podsuwał ją już Kwintylian [...]) jest ekscytujące nagromadzenie wydarzeń. Wydarzenia muszą być przy tym niedorzeczne lub niezwykłe. Oczywiście dużą rolę odgrywają tu elementy rytmu.

Umberto Eco, O literaturze ${ }^{2}$

Szachy to kamień probierczy modelowania myślenia.

Beniamin Puszkin, Heurystyka

* Uniwersytet im. Adama Mickiewicza, Wydział Filologii Polskiej i Klasycznej, Zakład Historii Literatury XX wieku, Teorii Literatury i Sztuki Przekładu, e-mail: lapsang3@ amu.edu.pl.

${ }^{1}$ M. Kundera, Sztuka powieści, przeł. M. Bieńczyk, Warszawa 2004, s. 38-39.

${ }^{2}$ U. Eco, O literaturze, przeł. J. Ugniewska, A. Wasilewska, Warszawa 2003, s. 179.

${ }^{3}$ Cyt. za: J. Giżycki, Z szachami przez kraje i wieki, Warszawa 1984, s. 141. Zdaniem rosyjskiego badacza "Charakterystyczną cechą gry w szachy jest to, że szachista ma zazwyczaj do czynienia ze stale zmieniającą się sytuacją i stosownie do tego musi opracowywać coraz to nową strategię" - tamże, s. 142. W tym aspekcie widzimy dużą zbieżność pomiędzy szachami a historią, wbrew bowiem obiegowemu twierdzeniu historia nie jest nauczycielką życia, czymś powtarzalnym i dającym się, per analogiam, przewidywać; jak gra w szachy jest ona nieskończenie zmienna i każdorazowo nas zaskakuje, wymagając wciąż nowych strategii decyzyjno-poznawczych. 
Mimo że współcześnie teoria prozy jest rozbudowaną formą wiedzy, ostatecznie nadal nie wiadomo czym jest powieść. Ten nadgatunek, który pozwolił nam stać się nowoczesnymi, ironicznymi i naznaczonymi poczuciem humoru Europejczykami - jak dowodzi w swych esejach Kundera - nie poddaje się definicjom. Dlatego w użyciu wciąż stosowane są dodatkowe oznaczniki gatunkowe, jakby sięgający po nie badacze wierzyli, że pozwolą one przekonująco opisać ten, wymykający się poznaniu, kształt literacki. Jednym $z$ takich terminów jest „powieść historyczna”. Niejasne łączy się tu z niejasnym; amorficzna forma z historią, która sama bezskutecznie poszukuje dziś własnej tożsamości. Sięgając do Słownika terminów literackich możemy przeczytać, iż pojęcie to oznacza „powieść, w której świat przedstawiony umieszczony został $\mathrm{w}$ epoce traktowanej przez twórcę $\mathrm{i}$ jego odbiorców nie jako epoka współczesna, ale jako zamknięty okres dziejów ${ }^{4 \prime \prime}$. Niby proste i przekonujące, ale obecnie, $\mathrm{w}$ dobie narratywizmu, doskonale wiemy, że uznanie danego okresu za zamknięty ma charakter arbitralny, jak też jest labilnym ex post, nadawanym każdorazowo faktom przez interpretujący podmiot. Po drugie, mamy świadomość, że linie historyczności przebiegają niejednorodnie, nawet $\mathrm{w}$ obrębie zamkniętego topograficznie społeczeństwa, i to, co dla jednych jest zamkniętą przeszłością, dla innych wykazuje cechy aktualności. Wreszcie samo wytyczenie koniecznych elementów danego okresu nie jest możliwe, ich wielość sytuuje je bowiem $w$ niezliczonych przecinających się układach semantycznych. Inne, wskazywane $\mathrm{w}$ rzeczonej definicji, cechy powieści historycznej to: respektowanie prawdy historycznej i ścisła wierność realiom (z czym zupełnie nie można się zgodzić, analizując utwory, zwłaszcza nowsze, zaliczane do tego gatun$\mathrm{ku}$ ), oddanie istotnych problemów epoki (raczej wyinterpretowywanych jako istotne ${ }^{5}$ ), przechodzenie utworów historycznych w rozrywkowe (czyli zastosowana typologia wspiera się na słabych różnicach) i ich wyrazista fabuła (cokolwiek miałoby to znaczyć). Z kolei ze Słownika rodzajów i gatunków literackich dowiemy się, że omawiana tu postać piśmiennicza to „wielopostaciowy gatunek, którego liczne odmiany łączy intencja przedstawienia prawdy dziejowej przeszłości. Materiałem [...] są fakty historyczne połączone $\mathrm{w}$ różnych proporcjach z fikcją literacką, przy czym wymaga się [...] ścisłej wierności wobec faktu w przedstawieniu materialno-przestrzennego i czasowego tła" ${ }^{\prime \prime}$. Dyskusyjność przywołanej intencji, wręcz niebadalność tej kategorii, nieostrość granicy fikcja-fakt, jako że każda powieść zawiera jakieś fakty, a także dalszy warunek zachowania w tej odmianie powieści niezniekształconego przebiegu "znanej powszechnie historii” [podkr. P. G.] nie czynią cezury oddzielającej powieść historyczną od innych postaci prozy zabiegiem fortunnym. Być może zabrakło ustalenia morfologii gatunku w stylu Władimira Proppa, który skutecznie dowiódł, że próby

\footnotetext{
${ }^{4}$ Słownik terminów literackich, pod red. J. Sławińskiego, Wrocław 1998, s. 420.

${ }^{5}$ Co autorzy słownika w pewnym sensie zauważają: "Na kształtowanie p.h. wpływa sposób pojmowania dziejów w danym czasie, zasób wiedzy historycznej" (s. 421).

${ }^{6}$ Słownik rodzajów i gatunków literackich, pod red. G. Gazdy, S. Tyneckiej-Makowskiej, Kraków 2006, s. 568. Wierność „faktom” jest tu jednak czymś umownym, gdyż dopuszczalne jest ich swobodne podporządkowywanie woli autorskiej: „autor może wykorzystać materiał historyczny do własnej interpretacji i oceny współczesności" - tamże.
} 
sklasyfikowania i opisu bajek $\mathrm{w}$ oparciu o ich temat nie mają mocy teoretycznej; może też powodem słabości przywołanych definicji jest fakt, że powstawały one przed dokonaną współcześnie narratywizacją samej historii $\mathrm{i}$ ich autorzy nie dostrzegali narracyjnego charakteru minionych zdarzeń.

Mimo tych trudności pytania o granice powieści historycznej, o fenomen historyczności oraz o semantykę wyobraźni historyzującej pozostają zasadne, choć odpowiedzi wynikać powinny, w moim odczuciu, z innych strategii badawczych. Dlatego w poniższych rozważaniach chciałbym zaproponować namysł nad historycznością i powieścią historyczną poprzez analizę odmiany, która z pozoru nie ma z tamtymi wiele wspólnego, mianowicie poprzez interpretację praktyki powieści szachowej. Jest to oczywiście działanie eksperymentalne, przesuwające granice gatunkowe i pozwalające na zmianę dotychczasowej optyki interpretacyjnej.

W punkcie wyjścia należy postawić pytanie: czym w ogóle jest powieść historyczna? I czy powieść szachowa ma z nią cokolwiek wspólnego? Niewątpliwie istnieje obszar, który w sposób naturalny, wręcz bezrefleksyjny, łączymy z historią - to opis rozmaitych bitew, biografii ważnych dla losów świata postaci, przełomów ustrojowych czy artefaktów organizujących dawne formy życia, opis wypełniający przeciętny podręcznik do historii. Tak zawężony przedmiot historiografii nie wytrzymał jednak próby czasu i w sposób naturalny domagał się reinterpretacji oraz poszerzenia. Ostatnie stulecie przyniosło zatem istotne zmiany w pojmowaniu tego, co jest historyczne, proponując na przykład zwrot ku życiu codziennemu, ku rzeczom czy ku zwierzętom. Jednak najistotniejszych argumentów zmieniających stary paradygmat dostarczyły wpierw badania Robina G. Collingwooda, a potem hipotezy Haydena Whitéa. Pierwszy z nich połączył myślenie historyczne z wyobrażeniowością?. Tym samym szczegółowa kwerenda i jej opis ustąpiły miejsca pracy wyobraźni wybitnych historycznych myślicieli, którzy nadawali przeszłości niepowtarzalny, zdeterminowany własnym talentem narracyjnym, kształt:

Wyobraźnia - rekonstruuje tezy brytyjskiego myśliciela Witold M. Nowak - umożliwia historykowi odmalowanie przed nami, przedstawienie obrazu minionej rzeczywistości, minionej epoki i jej ludzi. Jest ona zasadą sztuki, dzięki której praca historyka nie jest czymś banalnym, nie pozostaje jedynie mniej lub bardziej krytycznym zestawieniem tego, co z trudem zebrane w archiwach. [...]. Rzecz jasna, działanie wyobraźni ma też drugą stronę. Bywa ono bowiem odpowiedzialne zarówno za pośpieszne uogólnienia, jak i za zwykłe zmyślenia - w przypadkach kiedy wyobraźnia staje się fantazją ${ }^{8}$.

A powieść? Tu władza wyobraźni jest jeszcze silniejsza i trudno byłoby się jej przeciwstawiać w imię wyimaginowanej historycznej prawdy.

${ }^{7}$ Zob. R. G. Collingwood, Autobiografia. Z dziejów mojego myślenia, przeł. I. Szyroka, Kraków 2013; W. M. Nowak, Robina G. Collingwooda filozofia historii, Lublin 2002, szczególnie rozdział Aprioryczna wyobraźnia historyczna.

${ }^{8}$ W. M. Nowak, Robina G. Collingwooda..., s. 146. 
I nawet jeśli, mimo dowartościowania siły imaginacji, Collingwood deprecjonuje jednak semantykę rzeczy drobnych:

Przypatrzmy się, w jaki sposób historyk przedstawia słynną mowę. Nie interesuje go żaden zmysłowy element zdarzenia: tonacja głosu mówcy, twardość ławek, głuchota starszego gentlemana w trzecim rzędzie. Koncentruje się na tym, co człowiek ów usiłuje komunikować [...] oraz na odbiorze, z jakim przemawiający spotyka się u publiczności',

to powieść, także powieść historyczna, nade wszystko hołduje rozpoznaniom Kundery - jest badaniem egzystencji poprzez szczegóły i epizody nasycone antropologiczną treścią. Jest przeto manifestacją tego, co ludzkie, manifestacją doświadczenia w ujęciu opisanym przez Ryszarda Nycza:

Rzeczywistość dostępna [...] staje się światem ludzkiego doświadczenia [...] to znaczy światem, który nie ukazuje się nigdy w pełni, a tylko o tyle i w tym stopniu, w jakim indagowany jest przez człowieka ${ }^{10}$.

Hayden White ${ }^{11}$, badając relacje pomiędzy historią a literacką, historyczną oraz narracyjną fikcją, określa status powieści historycznej w sposób wręcz paradoksalny. Nie tylko, za Michelem de Certeau, uznaje fikcję za wypartego innego dyskursu historycznego. Nie tylko oddziela rzeczywistość od prawdy (dla powieściopisarza istotniejszy byłby pierwszy aspekt, rzeczywistości prawdopodobnej; dla historyka drugi, prawdy rzeczywistości), choć granica pomiędzy tymi kategoriami jest problematyczna. Nade wszystko White stawia tezę, że „kiedy zaczynamy myśleć o sensie życia, historia jest wszystkim, do czego możemy się odwołać"12. Wyciąga z tego rozpoznania wniosek, iż postmodernizm, dalej powieść postmodernistyczna, dokonały zwrotu ku historii i są historyczne zarówno sensu largo, jak i sensu stricto. I jeśli wcześniej historia, nade wszystko dawna, dostarczała powieści faktów (casus Waltera Scotta), to, wraz z rozwojem i powieści, i historii, za przedstawicieli pisarstwa historycznego można uznać Dickensa czy Balzaka, a w postmodernizmie niemal każdego powieściopisarza; badacz wymienia tu między innymi tak "historyczne” powieści, jak Wyszłam za komunistę Philipa Rotha, biografię muzyka jazzowego pióra Michaela Ondaatje'a czy utopię Ralpha Ellisona Niewidzialny człowiek ${ }^{13}$. Sami postmoderniści zaś - dowodzi White - „wobec historii przyjmują postawę miłości połączonej z nienawiścią"14.

9 R. G. Collingwood, Autobiografia. Z dziejów..., s. 108.

${ }^{10}$ R. Nycz, Poetyka doświadczenia. Teoria - nowoczesność - literatura, Warszawa 2012, s. 213.

${ }^{11}$ Zob. H. White, Fikcjonalność przedstawień opartych na faktach oraz tenże, Fikcja historyczna, historia fikcjonalna i rzeczywistość historyczna, przeł. D. Kołodziejczyk i A. Żychliński, [w:] tenże, Proza historyczna, pod red. E. Domańskiej, Kraków 2009.

12 Tamże, s. 189.

${ }^{13}$ Wpisując tę powieść w tzw. „afrofuturyzm”, White podkreśla wizjonerski charakter powieści historycznej jako gatunku; nie dostrzega on gry intertekstualnej - utwór Ellisona powtarza wszak tytuł powieści fantastycznej Herberta G. Wellsa.

${ }^{14}$ Tamże, s. 194. 
Skoro powieść współczesna, a może powieść w ogóle, ze swej natury jest historyczna, o ile zgodzimy się z diagnozą White'a, to należy postawić zagadnienie w sposób fundamentalny - albo wyróżnianie takiego gatunku jak powieść historyczna nie ma już sensu, albo musi istnieć byt, który powieścią historyczną nie jest.

Nim zaproponuję rozwiązanie tego rudymentarnego dylematu, chciałbym lakonicznie wspomnieć jeszcze o trzech tekstach. W Historii niebyłej ${ }^{15}$ Alexander Demandt zadaje pytanie: czy warto analizować zdarzenia, które nie miały miejsca?, dając odpowiedź pozytywną oraz sytuując taki proces badawczy jako pełnoprawny w przestrzeni doświadczenia historycznego. Fikcjonalizacja refleksji nad historią i potencjalna historiografia (notabene chleb powszedni prozy historycznej) są według niego sposobem, by odkryć jakości inne, niż powiązane ze sobą fakty mianowicie wpływ przypadku na zdarzenia, rolę ryzyka $\mathrm{w}$ działaniach postaci, znaczenie wyobraźni $\mathrm{w}$ rozumieniu procesów dziejowych czy węzłową strukturę historii:

Szereg czasowy sytuacji decyzyjnych nadaje historii szczególną strukturę, strukturę węzłową. Przez jakiś czas wszystko przebiega gładko, potem pojawia się węzeł, następuje zwrot. [...] sprawy przybierają odmienny kształt nie powoli i stopniowo - decyduja momenty wielkich kryzysów (Ranke) [...]. Historia biegnie naprzód krętą ścieżką, chybia celu, koryguje swe błędy, popełnia nowe i w ten sposób utrzymuje się w ruchu. Prądy i zawirowania tworzą rodzaj płynnej równowagi ${ }^{16}$.

Nieredukowalną stałą jest tutaj upływ czasu. „Bez pamięci - mówi Ernst Pöppel - nie możemy przeżywać trwania"17, bez trwania, ale i bez zakłócającej trwanie katastrofy, warunkującej zróżnicowanie zdarzeń, nie byłoby ani historii, ani powieści historycznej. Dziś jednak mamy już świadomość, iż „trwanie życia oceniane jest nie według kalendarza, numerycznie według dat, lecz według przeżyć, według znaczących treści"18. Wiedzę tę wcześniej od nauki posiadła powieść, co podkreśla słuszność rozpoznań narratywizujących doświadczenie historyczne oraz historiografię. Zdaniem Kazimierza Bartoszyńskiego ${ }^{19}$, w przypadku powieści historycznej mówimy o swoistej umowie, o grze w powieść historyczna. Grze, którą cechują następujące zasady:

- dostępność i zrozumiałość historycznego świata przedstawionego w powieści, co polega na tym, że czytając powieść historyczną, musimy doświadczać z jednej strony uniwersalności, z drugiej konwencjonalizacji i stereotypizacji;

\footnotetext{
${ }^{15}$ A. Demandt, Historia niebyła. Co by było, gdyby...?, przeł. M. Skalska, Warszawa 1999.

${ }^{16}$ Tamże, s. 153-154.

${ }^{17}$ E. Pöppel, Granice świadomości. O rzeczywistości i doznawaniu świata, przeł. D. Tauszyńska, Warszawa 1989, s. 98.

${ }^{18}$ Tamże, s. 96.

${ }^{19}$ K. Bartoszyński, Konwencje gatunkowe powieści historycznej, „Pamiętnik Literacki” 1984, z. 2 , s. 3-44.
} 
- usytuowanie aksjologiczne zdarzeń oraz obdarzenie sensownością faktów historycznych, przy braku granic dla ich wyboru, w myśl zasady Heglowskiej - każde drzewo ma swoją historię;

- usytuowanie zdarzeń w czasie uznanym za miniony;

- założenie prawdziwości zdań odnoszących się do historii i, równocześnie, umowności świata przedstawionego;

- nieustanne odnoszenie tego, co historyczne, do teraźniejszości ${ }^{20}$.

W tym miejscu, podsumowując jednocześnie dotychczasowe ustalenia, należy powrócić do pytania ogólnego: czym jest powieść historyczna? Otóż z całą pewnością nie można jej definiować poprzez kryterium tematyczne, jej przedmiotem mogą być bowiem dowolne zdarzenia. I w zasadzie każde usytuowanie w jakimś wczoraj, czy raczej w nie dziś, jest wystarczającą cezurą czasową, by dane fakty uznać za historyczne. Skoro tak, to proza tego typu z potocznie pojmowaną historycznością może mieć niewiele wspólnego; dla przykładu Honoriusz Balzak, opisujący upadek drukarstwa opartego na prasie drewnianej ${ }^{21}$, przedstawia doświadczenie historyczne, w które wpisuje opowieść miłosno-obyczajową. Czy można w ogóle wyobrazić sobie twór literacki umieszczony jedynie w wiecznym dziś? Byłyby to oczywiście powieści uniwersalne, dziejące się w jakimś nieokreślonym miejscu i czasie, najlepiej moralitety lub niektóre eksperymentalne powieści awangardowe. I tylko one nie wpisywałyby się w analizowany tu gatunek. Jednakże tak szeroka definicja powieści historycznej (jako dzieła określonego przez dowolne wczoraj) jest definicją słabo operacyjną poznawczo. Nie rozwiązuje też sprawy, wskazane przez Bartoszyńskiego, aktualizowanie tekstu historycznego przez odnoszenie go do teraźniejszości czy nakładanie na literackie postacie historycznej świadomości właściwej dla opisywanego czasu. Problem należy zatem rozwiązać inaczej.

W moim przekonaniu, by zdefiniować powieść historyczną, należy wziąć pod uwagę następujące komponenty, konieczne dla analizowanego doświadczenia:

1) katastrofę

2) referencję

3) pojedynczość doświadczenia literacko-historycznego

4) podwójną świadomość intencjonalną

5) zmienność paradygmatyczną historyczności

6) wyobraźnię.

Ad. 1. Gdyby w naszym świecie nie zachodziły widoczne dla człowieka zmiany, nie byłoby w nim historii. Dzianie się zakłada ruch, przemieszczenie, modyfikację, wytworzenie nowości. By zmiana mogła zostać dostrzeżona i rozpoznana jako zmiana, musi mieć gwałtowny i wyrazisty charakter, ujawnić się jako katastrofa transformująca czasoprzestrzeń. By dało się ją analizować temporalnie, jako zdarzenie, to suma (apriorycznie wybranych) wydarzeń poprzedzających zmianę musi dać się znarratywizować jako historia narastania kryzysu, prowadzącego do katastrofy. Późniejsze

\footnotetext{
${ }^{20}$ Tamże, s. 7-37.

${ }^{21}$ W powieści Dwaj poeci, przeł. T. Żeleński-Boy, Warszawa 1972.
} 
konsekwencje (faktu uznanego przez interpretatora za katastrofę) domykają opowieść (historyczną) o wytworzeniu nowego porządku, dając finalnie interpretację, gwarantującą faktom logiczne następstwo i znaczenie.

Historia zogniskowana wokół katastrofy może jednak być opowiedziana na różne sposoby, zależne od sensu, jaki nadajemy kluczowemu wyobrażeniu. Pojęcie „katastrofa” jest bowiem terminem epistemologicznym i wymaga dalszych uściślen. W swojej propozycji sięgam po jego interpretację dokonaną przez René Thoma, twórcę teorii przejść nieciągłych, zwaną też teorią katastrof. Koncepcję tę należy oczywiście przetransponować z obszaru nauk ścisłych do humanistyki i wyzyskać jej moce metaforyczne i obrazowe. W największym skrócie dla Thoma nie istnieją "fakty w sobie, fakty $w$ stanie surowym. Fakty powinny być raczej dostrzegane w związku z jakąś problematyką, są one odpowiedziami na pewien typ pytań"22. Zinterpretowane przez myślenie teoretyczne mogą tworzyć szeregi ewolucyjne (trwanie) lub systemy nieciągłe, te zaś opisuje teoria katastrof. Oczywiście takim nieciągłym systemem jest historia i badająca ją powieść historyczna. Ponieważ katastrofa jest faktem zmodyfikowanym przez jego rozumienie, jej wybór jest arbitralny i podlega naukowej negocjacji. Same katastrofy - wyprowadzone z koncepcji osobliwości (upraszczając, osobliwość to miejsce przecięcia wielu dróg, docelowo konotujące nieskończoność) w czterowymiarowej przestrzeni - zostały przez Thoma wyrażone nie tylko w postaci matematycznych symboli, ale też opisowo. Wyróżnił on siedem katastrof elementarnych (ich system nie jest ani zamknięty ${ }^{23}$, ani też całkowicie zbadany, to raczej koncepcje interpretacyjne, po które należy, w moim odczuciu, odważniej sięgać w humanistyce): fałdę, zmarszczkę (przyjmującą formę kolca, szpicu), jaskółczy ogon, umbilikę $e^{24}$ hiperboliczną, umbilikę eliptyczną, umbilikę paraboliczną i motyla ${ }^{25}$. Możemy, w odniesieniu do historii ${ }^{26}$, przykładowo przeanalizować zmarszczkę - mielibyśmy tu do czynienia z sytuacją, w której zachodzące około katastrofy zdarzenia nie formułują się w spójną całość, nie dają się ująć nadrzędnej kompleksowej narracji, przeciwnie - tworzą alternatywne, niezależne od siebie, równorzędne mikrohistorie, owe kolce, wystające niczym pagórki, z własną logiką i własnym znaczeniem. Każda narracja historyczna zdeterminowana zmarszczką będzie dążyć do ukazania, że katastrofa była centralnym punktem kilku równoległych i równorzędnych historii, które nie tworzą homogenicznej struktury znaczeniowej. W umbiliku parabolicznym natomiast zdarzenia poprzedzające i następujące po momencie katastrofy - niczym $\mathrm{w}$ paraboli logicznie i harmonijnie zbiegałyby się w owym kryzysowym pępku (kryzys

${ }^{22}$ R. Thom, Parabole i katastrofy. Rozmowy o matematyce, nauce i filozofii, przeł. R. Duda, Warszawa 1991, s. 64.

${ }^{23}$ „Teoria katastrof elementarnych nie wyczerpuje teorii katastrof. [...] wypada powiedzieć, że modelowanie ogranicza się dotychczas do zmarszczki, podczas gdy osobliwości wyższych rzędów [...] jeszcze nigdy nie zostały zastosowane" (to rok 1980) - tamże, s. 79.

${ }^{24}$ Od łac. umbilicus - pępek. Koncepcja jaskółczego ogona zainspirowała Salvadora Dalego (obraz: Ogon jaskótki i wiolonczela), który namalował jedną z Thomowskich katastrof.

${ }^{25}$ Tamże, s. 170, 105.

${ }^{26}{ }, \mathrm{~W}$ naukach humanistycznych natrafia się raczej na inne pojęcie formy [...]. Czyni to modelowanie tych nauk via teoria katastrof sprawą nadzwyczaj delikatną" - tamże, s. 86. 
to też akt poznania, zrozumienia istoty) i w podobny sposób zanikały wraz $\mathrm{z}$ upływem czasu.

Ad. 2. Utwór literacki ze swej natury jest fikcjonalny, toteż teoretycy literatury od lat zwalczają doszukiwanie się odniesień do rzeczywistych zdarzeń i postaci, wyśmiewając biografizm, wpływ, fałszywą referencję czy intencję autora. Wyrażał to z irytacją choćby Vladimir Nabokov, pisząc o arcydziele Flauberta:

Ale nie pytajmy, czy prawdziwy jest wiersz lub powieść. [...] Dziewczyna Emma Bovary nigdy nie istniała, powieść Pani Bovary będzie istnieć po wsze czasy. [...]. Doszło wręcz do oskarżenia powieści o obsceniczność i do procesu sądowego. Wyobraźcie sobie! Tak jakby dzieło artysty mogło być w ogóle obsceniczne. Z przyjemnością informuję, że Flaubert wygrał ten proces $^{27}$.

Jednakże, mimo od lat prowadzonej krucjaty antyreferencjalnej, są badacze, dla których odnoszenie tekstu do rzeczywistości nosi w sobie całą moc uroku fikcji - poszukują zatem ulic, po których chodzili bohaterowie Lalki Prusa, domu Sherlocka Holmesa czy (grę w referencję uwielbiał wszak Umberto Eco) miejsc spotkań trójki muszkieterów.

Inaczej historia - oczekujemy od historiografii, także od powieści historycznej, by fakty i ich wyjaśnienie były wiarygodne i miały umocowanie w rzeczywistości. Zarówno przeszłej, jak obecnej ${ }^{28}$. Tym samym powieść historyczna jest tekstem o podwójnej referencji - opisywane zdarzenia są literackie, czyli nierzeczywiste, fikcyjne, antymimetyczne; wiara, że proza ta opisuje coś więcej niż akty wyobraźniowe pisarza, jest nieporozumieniem. Jednocześnie nieustanne poszukiwanie tego, co zdarzyło się rzeczywiście, przeciwstawianie się „nieprawdzie” (gdy autor zwodzi swego czytelnika) jest wpisanym w tekst zadaniem odbiorczym. Wskazane podwojenie referencjalne pozwala nam dowolny tekst czytać historycznie (gdy weryfikujemy doświadczenie literackie w relacji do faktycznej przeszłości) lub pozahistorycznie (gdy ulegając fikcji, neutralizujemy dziejowość utworu). Tym samym sposób lektury determinuje istnienie gatunku.

Ad. 3. Relacja tekst-rzeczywiste zdarzenia, opisana wyżej, w układzie gry referencjalno-antyreferencjalnej, jest relacją jednokrotną i, niczym historia, nie powtarza się. Najlepiej wyjaśnić to na przykładzie. Opis historii ścięcia Jana Chrzciciela bądź opis podróży Odyseusza (jeśli weźmiemy pod uwagę również zdarzenia mitologiczne) jest praktyką historyczną i może wypełniać powieść historyczną. Powieści związanych z tymi wydarzeniami może być, co oczywiste, sporo. Każdorazowo przedmiotem refleksji jest opozycja tekstowe-rzeczywiste. Jeśli jednak zadamy pytanie o odniesienie do innych książek opisujących to samo, natychmiast opuszczamy historyczność i wchodzimy w przestrzeń intertekstualną. Rzecz przeto dotyczy świadomości czytelnika. Jeśli przeczyta on wiersz Guillaume’a Apollinaire'a

${ }^{27}$ V. Nabokov, Wykłady o literaturze, przeł. Z. Batko, Warszawa 2016, s. 201-202.

${ }^{28}$ Chodzi tu przykładowo o uznanie magii w świecie przedstawionym, przy założeniu, że wiemy, iż uznanie to dotyczy świadomości z minionego czasu. 
Salome ${ }^{29} \mathrm{w}$ oryginale lub $\mathrm{w}$ dowolnym tłumaczeniu i, przekonany, że biblijna przygoda miała miejsce $\mathrm{w}$ rzeczywistości, a Biblia jest tu dokumentem dla zdarzeń, zada pytanie, jak utwór ukazał tę historię, to dokona on lektury wiersza historycznego. Jeśli interesują go kolejne tłumaczenia, poszukuje różnic przekładu, ocenia wartość poetycką poematów czy powieści, to utwory, które analizuje, nie są (w danym akcie poznawczym) historyczne. Kolejny raz zatem nie struktura tekstu, a strategia odbioru określa gatunek.

Ad. 4. Albert Camus w Człowieku zbuntowanym ${ }^{30}$ zadaje ciekawe pytanie związane z królobójstwem: dlaczego ci, którzy zabijali króla, starali się zająć miejsce usuniętego władcy, zamiast znieść instytucję monarchii? Odpowiedź Camusa jest w pierwszej chwili zaskakująca - ponieważ nie potrafili sobie wyobrazić świata trwałego bezkrólewia. Katastrofa, którą wywoływali, nie niweczyła ciągłości ich myślenia o świecie w jego elementach koniecznych. Wynika z tego, że doświadczenie historyczne to nie tylko fakty, ale - może jeszcze bardziej istotne - sposoby rozumienia rzeczywistości. „Nie godzili w zasadę. Pragnęli innego króla. Nie wyobrażali sobie, że tron może pozostać pusty. Rok 1789 stanowi przełom: celem było obalenie zasady"31. Intencjonalność to fenomenologiczna koncepcja świadomości, nakierowanej na przedmiot. $W$ powieści historycznej nie tylko zderza się opisane wyżej nastawienie referencjalne $\mathrm{z}$ antyreferencjalnym, ale też nakładają się na siebie dwie intencjonalności. Rozum czasu przedstawianego i rozum czasu lektury. Każdy z nich jest nieodzowny. Ten pierwszy czyni przeszłość wiarygodną, wręcz pozwala przeszłości być historią; ten drugi pozwala dziejom zaistnieć $\mathrm{w}$ teraźniejszości, co jest nieodzownym warunkiem ważności analizowanego doświadczenia. Bez tej opozycji, warunkowanej głębokim rozumieniem (przez powieściopisarza) samej historyczności, mamy co najwyżej historyczną czytankę, pozbawioną istotnego znaczenia.

Ad. 5. Dopełnieniem podwójnej intencjonalności jest świadomość zmienności paradygmatu historycznego ${ }^{32}$. Jak przekonująco wskazuje John H. Arnold, rozumienie historii zmieniało się wielokrotnie. Raz badano dzieje, by zrekonstruować przeszłość, innym razem, by wyciągnąć naukę dla teraźniejszości; raz uważano, że historię tworzą wybitne postacie, innym razem, że manifestuje się ona w doświadczeniu codzienności; kontrapunktowano poznawanie minione rozmaitymi kontekstami: filozofią, biologią, matematyką. Uzasadniano fakty historyczne działaniem sił nadprzyrodzonych, sił rozumu lub przy padkiem. Materializm historyczny walczył z idealizmem. „Jak wynika z definicji - pisał Marc Bloch - przeszłość jest daną, której nic już nie zmieni. Ale znajomość przeszłości jest zmienną, ulegającą ciągłemu przekształcaniu"33. W efekcie trudno mówić o historii, zdecydowanie mamy do czynienia z historiami. I fakt ten jest głęboko wpisany $\mathrm{w}$ powieść historyczną, która zawsze uruchamia określony model ro-

\footnotetext{
${ }^{29}$ Zob. G. Apollinaire, Wybór poezji, Wrocław 1975, tu oryginał i pięć translacji wiersza.

${ }^{30}$ A. Camus, Człowiek zbuntowany, przeł. J. Guze, Warszawa 1998, s. 127-147.

${ }^{31}$ Tamże, s. 127.

${ }^{32}$ Zob. J. H. Arnold, Historia, przeł. J. Jaworska, Warszawa 2001.

${ }^{33}$ M. Bloch, Pochwała historii czyli o zawodzie historyka, przeł. W. Jedlicka, Kęty 2009, s. 73.
} 
zumienia przeszłości. Z tego też powodu historyczność powieści nie jest czymś stałym, raczej jest ową zmienną, która się powieści przydarza, toteż dziś powieści Aleksandra Dumasa uznamy chętniej za teksty przygodowo-awanturnicze niż historyczne, eposy Homera przesuniemy w przestrzeń mitu, a Balzaka uznamy za badacza uniwersalnych ludzkich namiętności. Odmawiamy dziełom miana historyczności, ponieważ paradygmat historyczny, który akceptujemy, nie jest tożsamy z paradygmatami rządzącymi tymi utworami. Tym samym sam gatunek jest formą labilną, tymczasową; zawiera strukturalnie w sobie własne zaprzeczenie. Jest żywą formą, która nieustannie się stwarza i destruuje.

Ad. 6. Mimo że każdy akt artystyczny jest tworem wyobraźni ${ }^{34}$, w przypadku powieści historycznej chodzi o coś więcej. Więcej nawet niż miał na myśli cytowany Collingwood, piszący o wyobraźni badawczej. Wyobraźnia jest bowiem warunkiem koniecznym zarówno samej historiografii ${ }^{35}$ :

Historyk - przekonuje Jacek Hajduk - tworzy swoje dzieła na wzór powieściopisarza tworzącego swoje. Historyk, opierając się na konkretnych danych, pisze więc swoje prawdziwe powieści (E. H. Kaplan). Nie wolno mu, oczywiście, zmyślać postaci i zdarzeń, ale to w jego gestii leży, jak skomponowana zostanie fabuła. Ta ostatnia zaś - na prawach domagania się - determinuje, które z faktów historyk pozyska ze swoich zasobów źródłowych, a które jako mniej interesujące porzuci (często skazując na zapomnienie) $^{36}$,

jak powieści historycznej, i - jak pisał Thom, głosząc pochwałę indeterminizmu: „wszystko co jest ściśle, jest bez znaczenia" ${ }^{37}$.

Wyobraźnia jest niezbędną jakością powieści historycznej, ponieważ proza tego typu jest formą (literackiego) badania przeszłości poprzez kreację artystyczną; badanie zaś, jako akt twórczy, wymaga wyobraźni, pozwalającej ustalić relacje między nieznaczącymi, niepowiązanymi faktami (danymi historycznymi), co czyni z nich zdarzenia, które tworzą zarówno literacką fabułę, jak i narrację historyczną (poznawczą). Ta natomiast, dzięki sile wyobraźni, staje się pewna, prawdziwa, nienaruszalna w swym znaczeniu, czy - jakby chciał Gaston Bachelard - kosmiczna:

Dotykamy tu jednego z paradoksów wyobraźni: podczas gdy myśliciele odtwarzający świat zakreślają długą drogę refleksji, obraz kosmiczny jest bezpośredni. Przed częściami ujawnia nam najpierw całość. [...]. Obrazy

34 „Pisać to dotykać nieznanego. Zanim człowiek przystąpi do pisania, zupełnie nie wie, co napisze. W pełni świadomości" - M. Duras, Pisać, przeł. M. Pluta, Izabelin 2001, s. 48.

${ }^{35}$ Jej znaczenie dla sensowności badań historycznych jest dziś uważane w zasadzie za bezsporne. Zob. m.in. M. Woźniak, Wyobraźnia (historyczna) i jej rola w procesie badania przeszłości [online] http://cejsh.icm.edu.pl/cejsh/element/bwmeta1.element.desklight-8ee7e6bb-eb53-4b48-8cc8-bc8412cd9ea1/c/41-53_Wozniak.pdf (dostęp 05.09.2016); J. Hajduk, Wyobraźnia, przedstawienie, narracja. O literackości pisarstwa historycznego, "Sensus Historiae" 2014, nr 1.

${ }^{36}$ J. Hajduk, Wyobraźnia, przedstawienie, narracja..., s. 9.

${ }^{37}$ R. Thom, Parabole i katastrofy..., s. 107. 
nigdy sobie nie przeczą. [...]. Myśliciel świata jest bytem, który się waha. Marzyciel świata zaś mieszka w świecie, który został mu właśnie ofiarowany, od kiedy tylko świat otworzył się za sprawą obrazu ${ }^{38}$.

A powieść historyczna jest właśnie tym bytem, który pozwala nam bezpiecznie zamieszkać w świecie minionym.

Sumując: powieść historyczna jest gatunkiem labilnym; jest tekstem o podwójnej intencjonalności; zogniskowanym wobec katastrofy, rozumianej (dzięki sile wyobraźni) obrazowo; wpisanym w paradygmatyczność doświadczenia historycznego; odnoszącym się do rzeczywistości w sposób dialektyczny (referencjalno-antyreferencjalnie); minimalizującym własne uwarunkowania intertekstualne; determinowanym w swej historyczności przez strategie odbioru.

Jedną z najciekawszych realizacji prozy historycznej jest powieść szachowa $^{39}$, gatunek, który sam domaga się osobnego artykułu, na co nie ma tu miejsca. Dlatego powieść ta omówiona zostanie jedynie egzemplifikacyjnie, na niewielu, za to charakterystycznych, przykładach ${ }^{40}$. Można i należy postawić pytanie, dlaczego powieść szachowa. Co ma ona wspólnego z powieścią historyczną i w czym jej przywołanie wzbogaca dotychczasowe rozpoznania? Odpowiedź na pytanie pierwsze jest oczywista - skoro przedmiotem powieści historycznej może być w zasadzie wszystko, zatem mogą być i szachy; wpisuje się to również $\mathrm{w}$ dzisiejszy paradygmat historyczny, w którym historyka bardziej niż losy władców interesują przedmioty, kultura, formy ubioru, historyczne sposoby myślenia czy gry. Ważniejsze jest pytanie następne. Otóż szachy są dyscypliną z pogranicza nauki, sztuki i sportu, mającą swoją własną, niezmiernie bogatą, historię. Pojawia się przeto drugi, równoległy i równorzędny porządek historyczny. Tym samym historyczność powieści historycznej potęguje się i wzajemnie warunkuje. Obydwa doświadczenia, historia szachów i historia wpisana w powieść, nałożone na siebie, pozwalają usłyszeć, wskazany w motcie przez Umberta Eco, nieoczywisty rytm; specyficzny ton podwójnego doświadczenia historycznego, polifoniczną melodię, różniącą się od melodii innych sposobów ukazywania i rozumienia rzeczywistości. Zarazem szachy nie są tym samym, co inne dyscypliny sportowe $\mathrm{z}$ ich historią. Nie są, ponieważ ich terminologia, sposoby myślenia, które niosą, filozofia $\mathrm{w}$ nie wpisana, wszystko to jest znacznie bogatsze semantycznie i tworzy rzeczywistą historię podwójną.

Szachy ze swoją historycznością mogą wypełniać powieść historyczną w sposób prosty lub złożony. W pierwszym przypadku są one elementem fabuły, fragmentem ilustracyjnym, osią akcji, za każdym razem jednak czytelnik, nie znający tajników gry oraz szachowych niuansów, może niemal

\footnotetext{
${ }^{38}$ G. Bachelard, Poetyka marzenia, przeł. L. Brogowski, Gdańsk 1998, s. 200.

${ }^{39}$ Powieść szachowa i powieść historyczna oczywiście nie są tożsame, niemniej historyczna natura szachów czyni je, niejako z definicji, faktem historycznym.

${ }^{40}$ Lista powieści szachowych jest bardzo bogata. Znajdziemy tu zarówno "klasyczne” powieści historyczne, jak też kryminalne (Czarny koń zabija noca Jacka Roya), sensacyjne (Szachiści Davida Hooda) czy psychologiczne (Zugzwang Ronana Bennetta); również, co zapewne najczęstsze, formy łączone.
} 
w pełni zrozumieć utwór. Wskażmy trzy przykłady. W Gambicie tureckim Borisa Akunina główny bohater, doskonały gracz w karty, szachy i inne gry, jest - na froncie wojny rosyjsko-tureckiej - doskonałym strategiem: wyprzedza ruchy przeciwnika, unika pułapek, poświęca, by zyskać (gambit). Szachy są tu jedynie rodzajem języka, podsuwają użyteczne metafory pojęciowe i współtworzą obrazy mentalne. W satyrycznych 12 krzestach, napisanych przez Ilję Ilfa i Eugeniusza Pietrowa, służą humorowi. Bohater, Ostap Bender, zwany Wielkim Kombinatorem, rozgrywa symultanę zupełnie nie znając reguł gry ${ }^{41}$. Chcąc wyłudzić pieniądze za rozgrywkę od mieszkańców zapomnianej mieściny Wasiuki, udaje arcymistrza i przekonuje, że jego występ rozsławi miasto, sprawi nawet, że zostanie tu przeniesiona stolica państwa. Tekst literacki okazał się profetyczny. Siedemdziesiąt lat później, w Kałmucji, zbudowano miasteczko szachowe Nowe Wasiuki, z ulicą Ostapa Bendera, w którym rozegrano olimpiadę szachową. Z kolei w Arcymistrzu Piotra Bojarskiego ktoś pragnie zamordować mistrza świata Aleksandra Alechina, który ma rozegrać symultanę w Poznaniu. Sytuacja jest fikcyjna, a szachy stanowią jedynie interesujący anturaż kryminalnej intrygi.

Znacznie bardziej interesujące i ważne dla zrozumienia powieści historycznej (oraz doświadczenia historycznego w ogóle) są utwory wymagające od czytelnika sporej wiedzy szachowej. Tekstem takim jest Zapach miasta po burzy Olgierda Świerzewskiego. Obserwujemy w nim „walkę" dwóch narracji historycznych. Pierwsza opowieść dotyczy historii Związku Radzieckiego. Wydarzenia mają dokładne datacje dzienne, autor koncentruje uwagę na licznych faktach-katastrofach: zestrzeleniu cywilnego samolotu przez siły powietrzne ZSRR, wybuchu w elektrowni jądrowej, tragedii na stadionie Spartaka, wynikających z zaniedbań i bezmyślności dowództwa stratach ludzkich w wojnie w Afganistanie, zatonięcia podwodnego okrętu atomowego i śmierci załogi itd. A zatem fabuła determinowana jest odniesieniem do świata rzeczywistego i można by uznać powieść za kronikę życia codziennego $\mathrm{w}$ totalitarnym systemie. Ważniejszy jednak jest porządek wynikający z szachów. Fabuła bowiem oparta jest (katastrofa pępka parabolicznego) na meczu Anatolija Karpowa z Garrim Kasparowem ${ }^{42}$. Wszystkie zdarzenia przygotowują nas do udziału w pojedynku, który symbolicznie rozrywa historię na czas Związku Radzieckiego (Karpow) i Rosji Gorbaczowowskiej (Kasparow). Mamy opisy partii, ale też przygotowań przedmeczowych czy okresu dorastania młodego szachowego kandydata na mistrza świata. Po katastrofie widzimy odchodzenie starego mistrza, który poddając się na szachownicy, wybiera prywatność. Szachy są osią i istotą powieściowych zdarzeń. Ale (!) daty, osoby, zdarzenia zostały przesunięte w czasie, same zaś reguły meczów i rozegrane partie są wzięte z innych pojedynków. Historia szachów jest tu autentyczna - wszystkie zdarzenia miały miejsce, partie były grane, choć motywacje graczy to efekt wyobraźni

${ }^{41}$ Mimo to sposobem wygrywa jedną partię! Sposób jest dość prosty: „Ostap zdjął nieznacznie z szachownicy czarną wieżę i schował ją do kieszeni. [...]. Dopiero tu stała moja wieża! [...]. Nie ma, a więc nie było! - odrzekł gburowato Ostap" - I. Ilf, E. Pietrow, 12 krzeset, przeł. T. Magister, Warszawa 1998, s. 248.

${ }^{42} \mathrm{~W}$ powieści występują jako Anatolij Romancew i Oleg Antonow. 
twórczej (przykładowo Karpow-Romancew poddaje wygrany mecz, traktując to jako symboliczną ekspiację za zdobycie kobiety - ukochanej jego szachowego rywala). Jednocześnie historia szachów w żadnym jej elemencie nie jest autentyczna - opisywane zdarzenia szachowe odbywały się $\mathrm{w}$ innym czasie, innym miejscu, brały $w$ nich udział inne osoby, rozgrywano inne partie. Można to zrozumieć w ten sposób, że historia wojen, zabójstw, ludzkiej śmierci jest jednorazowa, ścisła datacja jest znakiem pamięci; ale też historia ta dokonuje się nieustannie i jest doświadczeniem atemporalnym. Wojny szachowe doskonale tę pozaczasowość egzystencji podkreślają - pojedynek trwa i jest "ahistoryczny”, wieczny. Jednocześnie dla znawcy szachów i literacką zabawą, i intelektualnym wyzwaniem jest konfrontacja dwóch przenikających się historii w poszukiwaniu prawdy fikcji i prawdy egzystencji. Zarazem same zdarzenia tworzą katastrofę zmarszczki - mamy przed sobą równoległe światy alternatywne o własnej logice, wynikające z tych samych zdarzeń, lecz budujące odrębne mikronarracje.

Ważną powieścią jest też Ósemka Katheriny Neville. Fabularnie obserwujemy dwa plany historyczne - współczesny świat, postrzegany z perspektywy amerykańskiej, przenika się z okresem francuskiej rewolucji. W obydwu czasach toczy się gra - postacie pragną zdobyć komplet szachów Karola Wielkiego, który, według legendy, zapewnia panowanie nad światem. Autorka uruchamia tu zapomniane dziś znaczenie szachów - dawno temu niektórzy uważali tę grę za coś metafizycznego, związanego z gnozą, boskością, magią. Ten aspekt otwiera powieść na nauki i sztukę starożytną oraz prowadzi czytelnika do rozważań nad alchemią, liczbowym charakterem bytu opisywanym przez Pitagorasa, kultem bogów babilońskich, zachowanym za pośrednictwem starożytnego Tyru, a finalnie do pytania o boski prajęzyk, utracony $\mathrm{w}$ katastrofie wieży Babel. Z historycznego punktu widzenia powieść Neville pokazuje, że w historycznej narracji fakty są wybierane arbitralnie i ich udział w opowieści historycznej wynika z mocy wyobraźni. Utrata boskiego języka stwarzającego świat i dającego nieśmiertelność, czy raczej ludzka wiara $\mathrm{w}$ istnienie takiego języka, symbolicznie wyrażana w postaci noumenu - kamienia filozoficznego, jest katastrofą motyla, zatem determinuje wszystkie dalsze zdarzenia ze słabnącą siłą. Szachy, w swej gnostyckiej wykładni, pozwalają wydarzeniom utrzymać spójność i zapewniają narratywizowanej historii ciągłość oraz sensowność, są bowiem doskonałym narzędziem pozwalającym zrozumieć, przez analogię, rzeczywistość. Wyraził to najlepiej Italo Calvino:

Pomyślał: Skoro każde miasto jest jak partia szachów, w dniu, kiedy uda mi się poznać jego reguty, posiądę wreszcie moje cesarstwo, nawet jeśli nigdy nie zdołam poznać wszystkich miast, które zawiera. [na szczęście - P. G. - nikt nigdy nie zdołał poznać wszystkich reguł tej gry, nawet Wielki Chan] [...]. Wielki Chan usiłował wczuć się w grę, ale teraz wymykał mu się jej cel. Każda rozgrywka prowadzi do wygranej lub przegranej: ale czego? Co jest prawdziwą stawką? Przy macie, pod stopą króla, zmiecionego dłonią zwycięzcy pozostaje czarny lub biały kwadrat. [...] doszedł do krańcowej operacji: ostateczny podbój, dla którego wielokształtne skarby imperium 
były tylko złudną powłoką, sprowadzał się do kawałka oheblowanego drewna, do nicości ${ }^{43}$.

Chan pomylił się, jego pesymistyczne rozpoznanie filozoficzne jest prawdziwe tylko w połowie, celem gry jest bowiem sama gra, której, jak historii, nigdy nie uda się zrozumieć. Przekracza ona bowiem życie pojedynczego człowieka. I to jest ostateczna mądrość powieści historycznej, która, łącząc się z powieścią szachową, wyraża prawdy ponadhistoryczne, otwierając nas na ontologię i epistemologię wiedzy.

\section{B I B LIO GR A F I A}

Apollinaire G., Wybór poezji, Wrocław 1975.

Arnold J.H., Historia, przeł. J. Jaworska, Warszawa 2001.

Bachelard G., Poetyka marzenia, przeł. L. Brogowski, Gdańsk 1998.

Balzac H., Dwaj poeci, przeł. T. Żeleński-Boy, Warszawa 1972.

Bartoszyński K., Konwencje gatunkowe powieści historycznej, „Pamiętnik Literacki" 1984, z. 2.

Bloch M., Pochwała historii czyli o zawodzie historyka, przeł. W. Jedlicka, Kęty 2009.

Calvino I., Niewidzialne miasta, przeł. A. Kreisberg, Kraków 2005.

Camus A., Człowiek zbuntowany, przeł. J. Guze, Warszawa 1998.

Demandt A., Historia niebyła. Co by byto, gdyby...?, przeł. M. Skalska, Warszawa 1999.

Duras M., Pisać, przeł. M. Pluta, Izabelin 2001.

Collingwood R.G., Autobiografia. Z dziejów mojego myślenia, przeł. I. Szyroka, Kraków 2013.

Eco U., O literaturze, przeł. J. Ugniewska, A. Wasilewska, Warszawa 2003.

Giżycki J., Z szachami przez kraje i wieki, Warszawa 1984.

Hajduk J., Wyobraźnia, przedstawienie, narracja. O literackości pisarstwa historycznego, "Sensus Historiae” 2014, nr 1.

Ilf I., Pietrow E., 12 krzeset, przeł. T. Magister, Warszawa 1998.

Kundera M., Sztuka powieści, przeł. M. Bieńczyk, Warszawa 2004.

Nabokov V., Wykłady o literaturze, przeł. Z. Batko, Warszawa 2016.

Nowak W.M., Robina G. Collingwooda filozofia historii, Lublin 2002.

Nycz R., Poetyka doświadczenia. Teoria - nowoczesność - literatura, Warszawa 2012.

Pöppel E., Granice świadomości. O rzeczywistości i doznawaniu świata, przeł. D. Tauszyńska, Warszawa 1989.

Stownik rodzajów i gatunków literackich, pod red. G. Gazdy, S. Tyneckiej-Makowskiej, Kraków 2006.

Słownik terminów literackich, pod red. J. Sławińskiego, Wrocław 1998.

${ }^{43}$ I. Calvino, Niewidzialne miasta, przeł. A. Kreisberg, Kraków 2005, s. 101-104. 
Thom R., Parabole i katastrofy. Rozmowy o matematyce, nauce i filozofii, przeł. R. Duda, Warszawa 1991.

Woźniak M., Wyobraźnia (historyczna) i jej rola w procesie badania przeszłości [online] http://cejsh.icm.edu.pl/cejsh/element/bwmeta1.element.desklight-8ee7e6bb-eb53-4b48-8cc8-bc8412cd9ea1/c/41-53_Wozniak.pdf (dostęp 05.09.2016).

White H., Proza historyczna, pod red. E. Domańskiej, Kraków 2009.

\section{STRESZCZENIE}

Artykuł realizuje dwa cele. Pierwszym z nich jest ponowne zdefiniowanie gatunkowe powieści historycznej w sytuacji, w której dotychczasowe próby opisania tej formy okazują się niewystarczające. Nowa definicja przenosi punkt ciężkości z cech strukturalnych (niemożliwych do ustalenia po doświadczeniu narratywizacji historii) na poetykę odbioru. Cel drugi, interpretacyjny, polega na skomplikowaniu uczynionych rozpoznań poprzez analizę powieści szachowej, która multiplikuje historyczność utworu i zmusza do postawienia innych pytań. Tym samym artykuł zmierza do alternatywnego opisu ważnego dziś doświadczenia literackiego, jakim jest proza historyczna.

\section{Słowa kluczowe}

powieść historyczna, powieść szachowa, proza historyczna, recepcja

\section{S U M M A RY}

The chess novel as historical novel. A somewhat puckish alternative of the genre

The article focuses on two purposes. On the one hand, it constitutes an attempt to redefine the genre of historical novel in the circumstances in which the attempts made so far have turned out to be insufficient. The new definition shifts the centre of gravity from structural features (which are impossible to be determined following the experience of the narrativization of history) to the poetics of reception. On the other hand, the article also has its interpretative purpose which entails complicating the results of the analysis through the scrutiny of the chess novel that multiplies the historicity of the literary work and triggers more questions to be raised. Thus, the article aims at an alternative description of historical prose as an important literary experience of today's world.

\section{Keywords}

historical novel, chess novel, historical prose, poetics of reception 